\title{
Management of healthcare waste in a small hospital
}

\author{
Gerenciamento dos resíduos de serviços de saúde em um hospital de pequeno porte
}

\author{
Gestión de los residuos de servicios de salud en un hospital pequeño
}

Révia Ribeiro Castro ${ }^{1}$, Otaciano Sales Guimarães ${ }^{1}$, Valdênia Maria Leandro de Lima ${ }^{1}$, Conceição Delne Freitas Lopes $^{1}$, Emília Soares Chaves ${ }^{1}$

It aimed to conduct a situational analysis of the production and management of waste generated in a small hospital in the interior of the state of Ceará, Brazil, in 2014. Data collection occurred through systematic observation using checklist to verify routine procedures and questionnaires applied with the manager and employees responsible for hospital sectors. In the waste, it were found biological materials, anatomical parts, product of fertilization without vital signs, laboratory samples leftovers, containers and materials resulting from the health care process, chemical, household and sharps waste. It was verified improperly discarded waste according to current regulations. It is concluded the need for information and training of professionals who handle and dispose of healthcare waste.

Descriptors: Waste of Health Services; Waste Management; Public Health.

Objetivou-se realizar diagnóstico situacional da produção e manejo dos resíduos gerados em um hospital de pequeno porte no interior do Ceará, Brasil, em 2014. Dados coletados pela observação sistematizada utilizando checklist para verificação de procedimentos de rotina e aplicação de questionários, realizados junto ao gestor e funcionários responsáveis pelos setores hospitalares. Foram encontradas nos resíduos materiais biológicas, peças anatômicas, produto de fecundação sem sinais vitais, sobras de amostras laboratoriais, recipientes e materiais resultantes do processo de assistência à saúde, resíduos químicos, comuns e perfurocortantes. Verificaram-se resíduos descartados de forma inadequada conforme normas vigentes. Conclui-se ser necessário informar e capacitar profissionais que manuseiam e descartam resíduos de ambiente hospitalar.

Descritores: Resíduos de Serviços de Saúde; Gerenciamento de Resíduos; Saúde Pública.

El objetivo fue llevar a cabo diagnóstico situacional de la producción y gestión de los residuos generados en un pequeño hospital del interior del Ceará, Brasil, en año 2014. Los datos fueron recogidos mediante observación sistemática, utilizándose lista de verificación de procedimientos de rutina y aplicación de cuestionarios, realizados con el gerente y personal responsable por los sectores hospitalarios. Se encontraron en los materiales biológicos, piezas anatómicas, producto de fecundación sin signos vitales, sobras de muestras de laboratorio, contenedores y materiales resultantes del proceso de atención a la salud, residuos químicos, comunes y perfurocortantes. Se verificaron residuos descartados inadecuadamente, según reglas vigentes. En conclusión, son necesarias informaciones y formación de profesionales que manejan y eliminan residuos de ambiente hospitalario.

Descriptores: Residuos de Servicios de Salud; Gestión de Residuos; Salud Pública.

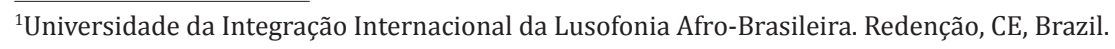

Corresponding author: Otaciano Sales Guimarães

Rua Maria Otília Pereira, 1175, Bom Nome. CEP: 62930-000. Limoeiro do Norte, CE, Brazil. E-mail: otaciano_enf@hotmail.com 


\section{Introduction}

Technological advances have been updating the health care assistance and, simultaneously, expanding the number of service-providing institutions, impacting the widespread increase in the waste produced by health services ${ }^{(1)}$.

Healthcare wastes consist of materials arising from activities related to the care offered to human and animal health, including those generated in units of diagnosis, treatment, home care, primary care, and hospital care of public, private and philanthropic institutions ${ }^{(2)}$.

Although healthcare waste represents a small portion of the total waste generated daily, it constitutes a risk component to the health of the general population when improperly managed, as it is a possible source of infection due to occupational accidents, and in the environment favors the appearance of rodents, vectors, in other words, sources to the spread of diseases ${ }^{(3-4)}$.

In Brazil, Resolutions No. 306 of the National Health Surveillance Agency, 2004, and No. 358 of the National Environmental Council, 2005, established the harmonization among regulatory entities about healthcare waste, shifting the responsibility of management to generators with the adoption of a management plan for healthcare waste. Including in the documents a set of procedures to be developed for its management in order to reduce risks to health, thus preserving the public health, natural resources and the environment ${ }^{(5-6)}$.

Although the waste management plan in health institutions is established by law, in practice, it can be observed the inadequate implementation of a management plan or its lack, whether for reasons of infrastructure, financial resources, human resources, or knowledge $\mathrm{e}^{(7)}$.

It becomes essential to discuss the management of healthcare waste on-site, as a way to foster the construction of a diagnosis of reality that enables to understand how the management takes place and verify its effectiveness to reduce the potential risks to health, environment and health problems, respecting the regulations established by Brazilian law.

The proper management of these wastes requires the planning of physical resources, materials and training of human resources involved in the handling of discarded materials and in the types and classification of waste produced, a process which is of legal responsibility of the generators ${ }^{(6)}$.

Management of healthcare waste involves steps that cover from its generation to final disposal, passing through the stages of separation, packaging, identification, internal transportation, temporary storage, external storage, external collection and transportation, treatment and final disposal ${ }^{(8)}$.

Segregation is the separation of the waste and should occur right at the source, in other words, when the waste is produced, separating them according to their physical, chemical, and biological characteristics and the risks involved. After segregation, packaging takes place in accordance with the type of waste ${ }^{(6)}$.

Internal transportation constitutes the transfer of waste from points of generation to the location of temporary storage (appropriate facility close to generating sources) or external storage (exclusive facility to guard the waste and with facilitated access to the process of external collection ${ }^{(9)}$.

As for the steps of external collection and transport, they consist in the removal of waste from the shelter to the treatment unit or final disposal, using techniques that preserve the conditions of storage and the integrity of workers, the public and the environment, in accordance with the guidelines of the urban cleaning entities ${ }^{(6)}$.

To minimize the risk of contamination, occupational accidents or damage to the environment, the treatment of healthcare waste is essential in the management process. This includes the implementation of methods, techniques or processes that change the characteristics of the risks related to waste $^{(8)}$.

Finally, the final disposal of healthcare waste 
emerges on the landfill of residues in soil previously prepared to receive them, according to technical criteria for construction, operation and environmental licensing ${ }^{(9)}$.

Thus, considering the importance of the subject in view of wastes from healthcare services and its regulations, and given the need for adequate management to reduce the risks to the health of professionals, population and the environment, the present study aims to develop a situational diagnosis from the analysis of production and management of waste in a small hospital.

\section{Method}

This is a field study research of descriptiveexploratory approach conducted in April 2014 in a public local small hospital located in the interior of the State of Ceará. This hospital is a municipal institution part of the care network of the Unified Health System and performs low and medium complexity services, focused on outpatient care, hospitalization, ancillary diagnostic service, therapy, and urgency.

It possess 28 beds distributed in internal medicine (16), pediatric clinic (6) and midwifery (6). In addition to these units, the hospital presents medical and statistical file service, administration, sterilization center, kitchen, pantry, pharmacy, laundry, laboratory, morgue, X-ray room, minor operation rooms, delivery room, plaster room, and outpatient care room. This institution was chosen as a research field due to the various types of medical hospital procedures performed, resulting in an accentuated and diverse waste production.

Data collection happened through systematic observation, to verify routine procedures, and questionnaires conducted along with the manager and other employees of the institution responsible for the hospital sectors.

Checklist type instruments were used, adapted from a study that addressed the management and evaluation of healthcare wastes $^{(6)}$. Issues guided by the standards of Resolution No. 306/04 of the National Health Surveillance Agency and No. 358/05 of the National Environmental Council were also used, whose variables of interest concerned the types of waste generated in the institution, the disposal by hospital units, and handling used by employees. A field diary was also applied to record data related to the generation and handling of wastes that were not included in the checklist.

Data analysis took into account the generation of waste by hospital sector and risk groups, and handling of waste according to the groups ${ }^{(8)}$.

Healthcare waste are classified into five groups according to their characteristics and peculiarities. Group A comprises potentially infectious waste; group $\mathrm{B}$, chemical waste; group $\mathrm{C}$ includes radioactive waste; group D, household waste; and finally, group E consist of sharps ${ }^{(8)}$.

Wastes of group A are subdivided into five subgroups, namely the subgroup A1 (biological materials such as culture, vaccine etc.); subgroup A2 (carcasses, body parts, entrails, and other waste from animals); subgroup A3 (anatomical parts, product of fertilization without vital signs); subgroup A4 (leftovers from laboratory samples, line kits, containers, and materials resulting from the health care process, etc.); subgroup A5 (organs, tissues, body fluids, sharps or scarifying materials and other materials resulting from health care to individuals or animals known or suspected to be contaminated with prion) ${ }^{(8)}$.

This research began after assent of the Research Ethics Committee of the Universidade da Integração Internacional da Lusofonia Afro-brasileira under protocol No. 611.635 and it was developed in compliance with the ethical principles established in current Resolution No. 466/12 of the National Health Council. 


\section{Results}

The waste produced in the institution appear in a diversified manner. In group A, were observed subgroups A1, A3 and A4, and waste from groups B, D and $\mathrm{E}$. There was no production of waste classified in group C and subgroup A2 and A5 (Figure 1).

Wastes produced in group $D$ are generated on all units, with especial reference to paper, diapers, food debris, sweeping waste, those from the administrative areas, and plaster waste. A few waste included in the subgroup A3 were observed in the delivery room, which were products of fertilization without vital signs and remaining placental tissue.
Two of the hospital units presented more diversified production of wastes: laboratory and minor operation room, which generate all other classes of waste found at the hospital, with the exception of subgroup A3. As for the medical and statistical file service, administration, sterilization center, pantry, kitchen and plaster room, they produced only wastes belonging to group D.

The hospital presents a variety of production of healthcare waste, however, during the segregation and identification of waste, it can be verified that the handling does not occur properly, because the residues produced in the units are not separated at the time of use, apart from sharps.

\begin{tabular}{|c|c|c|c|c|c|c|}
\hline \multirow{3}{*}{ Hospital units } & \multicolumn{6}{|c|}{ Groups } \\
\hline & \multicolumn{3}{|c|}{$\begin{array}{l}\text { A: Potentially } \\
\text { infectious }\end{array}$} & \multirow[t]{2}{*}{ B: Chemical waste } & \multirow[t]{2}{*}{$\begin{array}{l}\text { D: Household } \\
\text { waste }\end{array}$} & \multirow[t]{2}{*}{ E: Sharps } \\
\hline & A1 & A3 & A4 & & & \\
\hline Medical and statistical file service & & & & & $\mathrm{X}$ & \\
\hline Administration & & & & & $\mathrm{X}$ & \\
\hline Internal medicine & $\mathrm{X}$ & & & & $\mathrm{X}$ & $\mathrm{X}$ \\
\hline Pediatric clinic & $\mathrm{X}$ & & & & $\mathrm{X}$ & $\mathrm{X}$ \\
\hline Midwifery & $\mathrm{X}$ & & & & $\mathrm{X}$ & $\mathrm{X}$ \\
\hline Sterilization center & & & & & $\mathrm{X}$ & \\
\hline Kitchen & & & & & $\mathrm{X}$ & \\
\hline Pantry & & & & & $\mathrm{X}$ & \\
\hline Pharmacy & & & & $\mathrm{X}$ & $\mathrm{X}$ & \\
\hline Laundry & & & & & $\mathrm{X}$ & \\
\hline Laboratory & $\mathrm{X}$ & & $\mathrm{X}$ & $\mathrm{X}$ & $\mathrm{X}$ & $\mathrm{X}$ \\
\hline Morgue & $\mathrm{X}$ & & & & $\mathrm{X}$ & \\
\hline X-ray & & & & $\mathrm{X}$ & $\mathrm{X}$ & \\
\hline Minor operation room & $\mathrm{X}$ & & $\mathrm{X}$ & $\mathrm{X}$ & $\mathrm{X}$ & $\mathrm{X}$ \\
\hline Delivery room & $\mathrm{X}$ & $\mathrm{X}$ & $\mathrm{X}$ & & $\mathrm{X}$ & $\mathrm{X}$ \\
\hline Plaster room & & & & & $\mathrm{X}$ & \\
\hline Outpatient care room & $X$ & & & & $X$ & $X$ \\
\hline
\end{tabular}

Figure 1 - Distribution of healthcare waste generation according to hospital units 
Figure 2 shows compliance or not related to waste handling. It can be identified that during storage, as well as in segregation, only the group E, which includes sharps, presented some appropriate processes.

\begin{tabular}{|l|c|c|c|c|}
\hline \multirow{2}{*}{ Waste management } & \multicolumn{3}{|c|}{ Groups } & E: Sharps \\
\cline { 2 - 5 } & $\begin{array}{c}\text { A: Potentially } \\
\text { infectious }\end{array}$ & B: Chemical waste & D: Household waste & Yes \\
\hline Segregation & No & No & No & No \\
\hline Packaging & No & No & No & Yes \\
\hline Identification & No & No & No \\
\hline Internal collection and transport & No & No & No \\
\hline Internal storage & - & No & Yes & No \\
\hline External storage & No & No & No & No \\
\hline External collection and transport & No & No & Yes & No \\
\hline Treatment & No & No & No & No \\
\hline Final disposal & & No & No & No \\
\hline
\end{tabular}

Caption: In compliance with the rules=Yes; non-compliance=No

Figure 2 - Compliance or non-compliance of handling healthcare waste according to groups

In hospitals that have group A residues, there are two forms of packaging: waste is disposed of in waterproof and resistant milky white bags, and in other cases in blue bags. Nonetheless, different groups of waste deposited in any type of bag were observed. Additionally, wastes stored in sealed plastic containers with lid opening pedal system and damaged opening system were verified.

At the time of packaging, it was identified that group B residues generated by laundry, pharmacy, minor operation rooms, laboratory and X-ray room, namely medicines, laboratory reagents, sanitizers, disinfectants, image-processing effluents (developers and fixers), ether, formaldehyde, and acetone are packaged differently. From these wastes, medicines are packed in cardboard boxes, while the fixers are stored in plastic tubes that are later sold to recycling companies. The remaining residues of this group are not packed, being disposed of at the time of generation.
During on-site observation, it was found that the group D residues are packed sometimes in blue bags and other times in milky white bags with the symbol for infectious material. With regard to residues of group E, these are packaged in waterproof containers (boxes) resistant to puncture, rupture and leak, sealed and containing the substance symbol.

Watching the collection and internal transportation of waste of the abovementioned groups, it is noticed that they do not follow the definition of schedules, shifts and frequency of collections. Personal protective equipment required for the activity are not used, apart from boots, mask and gloves. Transportation occurs manually, without provision of garbage collection trolleys identified with the symbol of each residue.

As the hospital constitutes a small institution there is no temporary storage, after internal collection and transport, wastes are directed to the external 
storage location, in line with the regulations in force.

The external waste shelter consists of an exclusive closed facility for temporary warehousing of healthcare wastes, with storage capacity for up to three days. The floor, walls, doors and ceiling are made of washable and waterproof material in white, with cleaning after the external collection. The external storage door does not have the identification symbol for infectious substances, as well as during disposal of materials there is stacking of containers with the waste stored.

Despite the shelter, not all waste is stored there, rather only the residues of groups E and B, specifically expired medicines; nevertheless, there is no internal physical division in the shelter to keep them separate. The remaining residues belonging to group $\mathrm{A}$ and $\mathrm{D}$ are stored externally in the hospital yard in the open, in plastic and metal containers without lids.

With regard to the treatment of group A waste, from the vaccination room and laboratory, they undergo a process of inactivation. The remains of vaccines with live attenuated bacteria or virus arranged in jars go through autoclaving before being packed in boxes of sharps. The laboratory glassware containing the biological material are disinfected with a sodium hypochlorite solution and then sterilized in an oven. As for the disposable materials containing Group A residues, they go only through the process of disinfection with sodium hypochlorite and are then disposed of in ordinary trash containers.

Groups A and D residues are collected and transported by vehicles of the local urban waste collection system. Drugs with expired period of validity and the group E waste are collected and transported by a third party contracted by the hospital. Nonetheless, the collector vehicle does not present information regarding the municipality, the name of the company responsible, and the identification of transported waste, as well as does not undergo cleaning and disinfection after transporting healthcare waste.

The external collection and transport of waste does not occur in specific time, nor do the workers strictly use the equipment for individual and collective protection.

The final disposal of healthcare waste happens differently among the groups. The residues of group A and $\mathrm{D}$, with the exception of fertilization products, are dispensed in a cistern located in the hospital yard, the others are dispensed in open-air dumpsters outside the city. The expired drugs and residues in group E are disposed of in ditches and then incinerated.

Finally, it was found that the hospital does not have a management plan for healthcare waste, a necessary instrument for workers to meet the healthcare waste management process.

\section{Discussion}

Healthcare waste generated by hospital sectors does not differ from the results presented in other studies ${ }^{(7,10)}$, since household residues are present in most units. As regards the potentially infected materials, particularly the subgroup A1, these are present in the hospital sectors that perform the highest number of health procedures such as outpatient, delivery, minor operation, and internal medicine $\operatorname{room}^{(7,10)}$.

Segregation is the first step of waste management and is considered the most important one, since it determines the adequacy of the subsequent handling, recycling, occupational and environmental safety, besides reducing the volume of waste requiring different handling ${ }^{(1,11,8)}$. In the study hospital, segregation does not happen properly because only the group $\mathrm{E}$ residues are disposed of separately. It is observed that residues from groups $\mathrm{A}$ and $B$ are separated along with the group D waste.

Epidemiological study conducted in the city of Goiânia, state of Goiás, presented similar results to the present study: inadequate segregation of potentially infectious waste and sharps, which were segregated along with household thrash ${ }^{(7,10)}$.

The correct packaging of healthcare wastes avoids unnecessary exposure of workers to biological 
hazards and accidents, besides preventing the contact with living beings and the environment, facilitating an appropriate destination ${ }^{(1,5)}$.

It can be noted that in the packaging, only the group E residues undergo this process adequately: in resistant boxes that prevent puncture and rupture, and properly identified with sharps symbol. The remaining hospital waste does not comply with current resolution because the packaging process is partially adequate ${ }^{(9)}$.

According to the rules on packaging, potentially infected waste should be stored in white bags with the universal symbol of "Biohazard" or "Chemical Risk"(8); however, in the present study, it can be observed non-compliance with this requirement. As disclosed, infectious waste must be packaged in milky white color and waterproof bags. Nonetheless, the bags containing these residues are stored in washable containers, resistant against rupture and leak, lid with opening system, without manual contact, following that recommended by the Resolutions ${ }^{(9-6)}$.

Healthcare waste must be packaged in compliance with the requirements of chemical compatibility of waste among each other, and among these and the packing materials, in order to avoid chemical reactions that weaken or deteriorate these packs $^{(9)}$. Chemical wastes, as well as those potentially contaminated, are not packed properly, because the material of the packaging containers does not meet the requirement of chemical compatibility. Furthermore, the residues that are not packaged are disposed of in the sewage system at the time of their generation, without mention of previous treatment. The lack of adequate storage might be related to a concern with group E waste, at the expense of other wastes, even though the group B residues also present environmental and health risks ${ }^{(12)}$.

Identification of healthcare wastes and their containers occurs according to the content and the specific risk of these residues using appropriate symbols for each group ${ }^{(9)}$. Nevertheless, only the group E residues are identified. It is noted that this fact relates to the inadequacy of management in the previous steps, because the lack of segregation and adequate packaging in other stages directly influences the identification.

Despite the recommendations of the Board Resolution 306/04 of the National Health Surveillance Agency that highlights the need of collection and transportation to be developed by groups of residues, this aspect was neglected in the present study. This result differs from studies in the area, whose steps occur appropriately, being performed based on groups of residues ${ }^{(7-13)}$.

The lack and inadequacy of collection vehicles for internal transport may cause risk of injury to workers and excessive physical effort; and the lack of pre-established schedules for distribution of clothing, food and medicines extends the risk beyond the institution's employees, such as visitors, escorts and patients.

The non-use of personal protective equipment required for the employees responsible for the collection and internal transport exposes them to potential risks of accidents ${ }^{(11)}$.

The absence of a place for internal storage resembles that found in similar study ${ }^{(12)}$. Nonetheless, the lack of a space intended for internal storage does not disrespect the current resolution, as it is a small hospital $^{(8,12)}$.

After the stage of internal collection and transport, healthcare wastes are directed to the external storage facility, which partially meets the existing recommendations for handling these waste, since, regarding the structure of the site, it has is good lighting, washable floor and walls, and it allows a minimum ventilation. However, some recommendations are not met because the door does not contain the symbol to identify the existing waste, as well as the facility's structure does not allow the separation of waste by groups ${ }^{(14)}$.

Non-compliance in relation to the external transport is also observed in another study ${ }^{(15)}$. The residues of group $B$ and $D$, besides not being treated, 
are transported in non-standard vehicles, not ensuring the preservation of the packaging conditions and the integrity of workers, population and environment ${ }^{(15)}$.

The final disposal of healthcare waste in an open-air dump, except for the residues of group A3 that are deposited into the cistern in the hospital yard, does not meet the requirements by regulatory entities, as it is an inappropriate method of waste disposal, highly harmful to the health and environment. This provides an environment susceptible to the appearance of undesirable vectors, unpleasant odor, contamination of surface and groundwater, presence of waste pickers, and risk of explosions related to the generation of methane gas coming from the degradation of waste ${ }^{(15)}$.

Given the inconsistencies in waste disposal and managers who do not conform to regulations, it is important highlighting that the results of this research resemble those presented in other studies carried out in Brazil, where there is no use of a proper system for disposal of healthcare waste ${ }^{(7,12,16)}$.

\section{Conclusion}

In this research, it was identified that the management of healthcare waste is not being operated properly at the different stages of the process such as segregation, packaging, identification, collection, storage, transportation and final disposal, as established by resolutions in force in the country.

Although the management of healthcare waste at this institution has been effected irregularly, it is observed that the group $\mathrm{E}$ waste were handled appropriately in the steps of separation, packaging and identification. This way, it can be inferred that professionals identify sharps as relevant to occupational and health risks.

Knowing this reality enabled to build a situational diagnosis of the management, which is utterly important to identify which points of management require a more effective performance, and to reveal the need for further research to identify which reasons are not related to appropriate management at this institution and subsequently develop a management plan of these wastes.

It is important to conduct and support research related to the management of healthcare waste, because it highlights the urgent need for changes in relation to the management, not only in the institution of study as in various health institutions in the country, as well as the little recent scientific literature in health journals on this theme.

\section{Collaborations}

Castro RR, Guimarães OS, Lima VML and Lopes CDF contributed to the design, field data collection, analysis, interpretation of data, drafting of the article and final approval of the version to be published. Chaves ES contributed to the study design, drafting of the article and final approval of the version to be published.

\section{References}

1. Alves SB, Souza ACS, Tipple AFV, Rezende KCD, Rezende FR, Rodrigues EG. Manejo de resíduos gerados na assistência domiciliar pela estratégia de saúde da família. Rev Bras Enferm. 2012; 65(1):128-34.

2. Debere KM, Gelaye KA, Alamdo AG, Trifa ZM. Assessment of the health care waste generation rates and its management system in hospitals of Addis Ababa, Ethiopia, 2013. BMC Public Health. 2013; 13(28):3-9.

3. Centenaro WLA, Dallago RM, Centenaro AM. Gerenciamento de resíduos de serviços de saúde na microrregião geográfica de Erechim - RS. Perspectiva. 2012; 36(133):223-36.

4. Ventura SK, Reis LFR, Takayanagui AMM. Avaliação do gerenciamento de resíduos de serviços de saúde por meio de indicadores de desempenho. Eng Sanit Ambient. 2010; 15(2):167-76. 
5. Santos MA, Souza AO. Conhecimento de enfermeiros da Estratégia Saúde da Família sobre resíduos dos serviços de saúde. Rev Bras Enferm. 2012; 65(4):645-52.

6. Lasch FA, Wolff DB. Gerenciamento de resíduos de serviços de saúde: um estudo de caso. Disc Sci. 2010; 11(1):64-86.

7. Pereira MS, Alves SB, Souza ACS, Tipple AFV, Rezende FR, Rodrigues EG. Waste management in non-hospital emergency units. Rev Latino-Am Enfermagem. 2013; 21(n. spec):259-66.

8. Ministério da Saúde (BR). Resolução no 358, de 29 de abril de 2005. Dispõe sobre o tratamento e a disposição final dos resíduos dos serviços de saúde e dá outras providências. Brasília: Ministério da Saúde; 2005.

9. Ministério da Saúde (BR). Resolução da diretoria colegiada - RDC no 306, de 7 de dezembro de 2004. Dispõe sobre o Regulamento Técnico para o gerenciamento de resíduos de serviços de saúde. Brasília: Ministério da Saúde; 2009.

10. Gessner R, Piosiadlo LCM, Fonseca RMGS, Larocca LM. O manejo dos resíduos dos serviços de saúde: um problema a ser enfrentado. Cogitare Enferm. 2013; 18(1):117-23.
11. Oliveira NC, Moura ERF. Precauções básicas e gerenciamento de resíduos na coleta para o exame de papanicolaou. Rev Rene. 2009; 10(3):19-26.

12. Sales CCL, Spolti GP, Lopes MSB, Lopes DF. Gerenciamento dos resíduos sólidos dos serviços de saúde: aspectos do manejo interno no município de Marituba, Pará, Brasil. Ciênc Saúde Coletiva. 2009; 14(6):2231-8.

13. Gonçalves EMN, Santos CB, Badaró MLS, Faria VA, Rodrigues E, Mendes ME, et al. Modelo de implantação de plano de gerenciamento de resíduos no laboratório clínico. J Bras Patol Med Lab. 2011; 47(3):249-55.

14. Brasil. Resíduos sólidos: gerenciamento de resíduos de serviços de saúde: guia do profissional em treinamento: nível 2/ Ministério das Cidades. Secretaria Nacional de Saneamento Ambiental (org.). Brasília: Ministério das Cidades, 2008.

15. Melo CP, Barbosa LB, Souza MR, Barcelos ISC. Estudo descritivo sobre o gerenciamento dos resíduos de serviços de saúde no município de Jataí, Góias, 2010. Epidemiol Serv Saúde. 2013; 22(3):517-24.

16. Pereira SS, Lucena LL, Fernandes A. Resíduos de serviço de saúde em um hospital de Campina Grande/PB: gestão e percepção ambiental. Rev Bras Gestão Desenvolv Reg. 2010; 6(3):255-86. 